\title{
HEGEMONS, EMPIRES, AND THEIR ELITES
}

\author{
Richard Lachmann \\ State University of New York at Albany, United States of America
}

Resumo Comparo impérios antigos e modernos e mostro de que forma a hegemonia além da esfera militar é possível apenas no mundo capitalista moderno. Analiso a Alemanha, a Espanha e a França, que falharam no alcance da hegemonia, juntamente com três poderes hegemónicos sucessivos: Holanda, Grã-Bretanha e Estados Unidos. Identifico as elites que foram criadas e reforçadas pelos regimes imperiais ou hegemónicos dos seus países, e enumero fatores que permitiram a algumas elites coloniais alcançar elevados níveis de autonomia. A autonomia de certas elites coloniais ou os níveis elevados de unidade das elites das metrópoles impediram ou enfraqueceram a hegemonia.

Palavras-chave império, hegemonia, elites, colónias.

\begin{abstract}
I compare ancient with modern empires and show why hegemony beyond the military realm is possible only in the modern capitalist world. I examine Germany, Spain and France, which failed to achieve hegemony, along with the three successive hegemons: the Netherlands, Britain, and the United States. I identify the elites that were created and strengthened by their home polity's empire or hegemony, and enumerate the factors that allowed some colonial elites to achieve high levels of autonomy. Colonial elite autonomy or high levels of elite unity in the metropole prevented or undermined hegemony.

$\underline{\text { Keywords }}$ empire, hegemony, elites, colonies.

Résumé Cet article compare des empires anciens et modernes afin de montrer comment l'hégémonie au-delà de la sphère militaire n'est possible que dans un monde capitaliste moderne. Il analyse l'Allemagne, l'Espagne et la France qui ont échoué dans leur quête d'hégémonie, face à trois pouvoirs hégémoniques successifs : Hollande, Grande-Bretagne et États-Unis. Il identifie les élites qui ont été créées et renforcées par les régimes impériaux ou hégémoniques de leurs pays, tout en énumérant les facteurs qui ont permis à certaines élites coloniales d'atteindre des niveaux élevés d'autonomie. L'autonomie de certaines élites coloniales ou les niveaux élevés d'unité des élites des métropoles ont empêché ou affaibli l'hégémonie.
\end{abstract}

Mots-clés empire, hégémonie, élites, colonies.

Resumen Comparo imperios antiguos y modernos y muestro de qué forma la hegemonía además de la esfera militar es posible solamente en el mundo capitalista moderno. Analizo a Alemania, a España y a Francia, que fallaron en el alcance de la hegemonía, en comparación con tres poderes hegemónicos sucesivos: Holanda, Gran Bretaña y Estados Unidos. Identifico las elites que fueron creadas y reforzadas por regímenes imperiales o hegemónicos de sus países, y enumero factores que permitirán a algunas elites coloniales alcanzar elevados niveles de 
autonomía. La autonomía de ciertas elites coloniales o los niveles de elevados de unidad de las elites de las metrópolis impedirán o debilitarán la hegemonía.

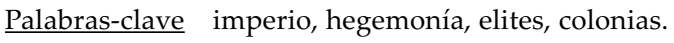

\section{Introduction}

All polities since the advent of capitalism, and almost all large-scale polities in the millennia before then, have been ruled by multiple elites. When a polity becomes an empire or a hegemon, or even a regional power, it gives rise to new elites, some of whom remain abroad and exert influence on metropolitan politics only indirectly, while others return home or exploit their polity's foreign holdings without ever leaving the metropole. The new elites alter the overall structure of elite and class relations within the imperial or hegemonic polity, creating new sorts of conflicts and a new dynamic of structural change.

Ancient empires, modern empires, and hegemons provide openings for different sorts of elites, and therefore have different dynamics of conflict and change. That is why the long-term survival and ultimate fall of the Roman (or other ancient empires) or even the Ottoman Empire provides few "lessons" for understanding the trajectories and ultimate fates of the United States or of the preceding capitalist hegemons. Similarly, the dynamics of non-hegemonic modern empires (such as the French, Hapsburg and Portuguese) differ in ways we must specify from that of empires that also were capitalist hegemons such as the British and Dutch. We also will need to analyze how the British and Dutch empires, and their interactions with their home polities, were transformed as they gained hegemony and again later when they lost it.

The differences among ancient and modern empires stem from the very different sorts of domination they were able to exert over conquered territories and peoples. Pre-capitalist forms of domination were based largely on brute military force and, at the local level, on kin networks. Only occasionally, and slowly and unevenly, did pre-capitalist empires built common ethnic or cultural identities, and they did so mainly among elites; even less often did they have any affect on the organization or technical level of production of the territories they conquered. As a result ancient empires were able to exert hegemony only in the military realm. Their control over the economy of conquered territories, and even of much of their homeland, was far from hegemonic. By contrast, modern forms of dominance have been able to rapidly and decisively transform the territories and peoples that they controlled. However, we will need to distinguish and theorize the differences between the dominance exerted by polities over their empires and the unique sort of domination exerted by a single hegemon during some periods over the past five hundred years.

Hegemony beyond the military realm, as we will see, became possible only with capitalism. Capitalism also made possible the rise of elites whose power was 
grounded in institutions that controlled markets and production even as they lacked the capacity themselves to use or threaten force. The high degree to which such elites are separated from military elites gives the hegemonic powers they inhabit a very different structure and dynamic than both pre-capitalist empires and modern empires or regional powers that were not also hegemons.

This article does not offer a critical review of the myriad definitions of empire. Those definitions all agree that empires differ from non-imperial polities in that they exert power over territories and peoples beyond their core polity, and that the essential dynamic of an empire is produced by the interaction between the core's efforts to sustain or expand and deepen its rule over peripheries and the peripheries' efforts to weaken or end the core's rule over them.

I want to step back from definitional debates to make a basic point that will guide my analysis. Empires exert a different sort of control than do hegemons, even though some hegemons have had empires and used them as one of the cornerstones of their hegemony. Those differences determine the sorts of pressures empires and hegemons endure internally and from those they subjugate, the opportunities they derive from their power, and most importantly give rise to different internal political dynamics. Imperial elites are different from hegemonic elites. My main goal in this article is to identify those differences. For the most part this article engages these issues at a theoretical level. The evidence to support my claims is presented in my forthcoming book, First Class Passengers on a Sinking Ship: Elite Privilege and the Decline of Great Powers, 1492-2010, which analyzes the actual hegemons and their main challengers over the past five hundred years.

I also will have very little to say in this article about how subjected peoples are affected by hegemonic or imperial domination. I do not seek to minimize the suffering that those who have been exploited by hegemons and empires endure. The contribution of this article lies not in adding to the rich literature on the victims of domination. Instead, I seek to analyze how dominant powers and their elites are transformed by their efforts to expand and maintain the realms in which they exercise power. Empires and hegemons, unfortunately, did not decline because they were brutal, and exposing that brutality does not help much in understanding their declines, although, as I will show, massive cruel violence was an essential element in the rise and continuation of imperial and hegemonic power.

I begin by defining elites and contrasting them to Marx's concept of a ruling class. Once we know what an elite is, we will be able to identify the elites in each sort of polity. That will provide the basis to explain how ancient empires, modern empires, and hegemons give rise to new elites in the course of achieving dominance over territories and peoples beyond their home polities. I want to show how the new elites in each of those sorts of polities relate to the old, domestically-based elites, and how conflicts between and among old and new elites produce dynamics that alternately strengthen and then undermine those polities' capacities to project power and extract resources from beyond their home territory. I undertake that task first by examining the Roman and Ottoman empires. That will be the only empirical portion of this article. The Roman Empire lasted longer and was larger than any other pre-capitalist empire. In 
exploring its achievements we will be able to identify the limits of all ancient empires. The Ottoman Empire allows us to see the limits of change in the pre-capitalist millennium that followed the fall of Rome.

This article then moves from the ancient to the modern, and from the empirical to the theoretical. I highlight the crucial ways in which capitalism and modern states are able to exert deeper forms of power over formal and informal dominions, and identify the sorts of elites that are created by the exertion of such powers. I offer a typology of modern empires, differentiating them in terms of (1) the extent to which colonial elites were autonomous from the metropole and (2) the degree to which colonial elites had influence over the metropolitan political economy. This typology will allow me to distinguish between those sorts of control, which can be deployed by multiple empires and polities simultaneously, and hegemonic power, which is exerted by only a single polity at a time. I conclude with a series of arguments about how the elites in hegemons generate dynamics of conflict that undermine hegemony.

\section{What is an elite?}

An elite is a group of rulers who inhabit a distinct organizational apparatus with the capacity to appropriate resources from nonelites. According to this definition, elites are similar to ruling classes in that both live by exploiting producing classes. However, elites differ from ruling classes in two significant ways: first, although in Marx's theoretical framework the fundamental interest of the ruling class is to reproduce its exploitative relation vis-à-vis the producing class, in my elite model this interest is complemented by an equally vital interest in guarding its existing power from, and extending its power at the expense of, rival elites; second, each elite's capacity to pursue its interests derives from the structure of relations among various coexisting elites as much as from interclass relations of production.

Elite conflict is the primary threat to elite capacities; yet, the interests each elite seeks to defend are grounded in their relations with the producing classes. Elite capacities change primarily when the overall structure of elite relations changes. ${ }^{1}$ The outright defeat and elimination of a rival elite is rare, and when it happens it produces a decisive change in overall social structure. More commonly, elite conflict ends in stalemate or produces incremental changes in elite powers and relations that only gradually transform the overall social structure of a society. Oftentimes, elites resolved their conflicts, and fended off challenges from nonelites, by combining themselves and their organizational capacities into a single institution. That was the main process that animated state formation. States were not for the most part created when kings used force to eliminate enemies on the battlefield or sent bureaucrats or soldiers from a capital to tax and control the hinterland. Force played a much greater role in the formation 
of empires than of states, yet elite combination and joint rule over complex imperial institutions was as much a part of the dynamic of empires as conquest and elimination. When multiple elites entered into a single institution, they often retained specific powers and exercised control over elements of that institution. Thus, it is a mistake to see states or empires as unified and operating under the direction of single ruler or elite, or setting policy according to a single logic.

Elites assert and exercise through their institutions a combination of economic, political, military and ideological powers as they seek to guard their interests against both rival elites and the nonelites from whom they extract resources. While the mix of those powers varies among elite institutions, almost never does an elite survive by relying exclusively or even primarily on a single form of power. It is an error, especially in the pre-capitalist world, to contrast political and economic, institutions. ${ }^{2}$ Even in the modern era elites inhabit institutions that simultaneously are state-like and imbricated in production in civil society. However, elites combined and exercised those powers in quite different ways in pre-state polities, ancient empires, modern empires, and nation-states. Those differences produce the different dynamics of each of those social formations. Similarly, we can understand differences among societies of each of those types (for example between the ancient Greek or Roman empires, or between the Dutch and British hegemon) by comparing the elite structures and conflicts of those societies. Elites in each of those societies were able to mobilize particular combinations of powers in their institutions. Their conflicts with each other and with nonelites were fought on terrains that were in part and simultaneously economic, political, ideological and military.

In sum, elites are defined by the organizations they inhabit, organizations that mobilize a combination of powers. Ultimately, the capacities of those organizations are determined by their position in the overall structure of a polity in which multiple elites jostle to appropriate resources from nonelites. For that reason, elites and their organizations occupy very different positions in empires, nation-states or hegemons. If the polity they inhabit gains or loses an empire, or attains or surrenders hegemony, elites come to assume different opportunities and capacities. The fundamental dynamics of ancient imperialism, modern imperialism, and capitalist hegemony generate particular sorts of elite relations and conflicts. We can identify the basic dynamics of each type and in that way highlight what is unique about the hegemons of the past five hundred years.

\section{Romans, Ottomans, and the limits of pre-capitalist empires}

Let us begin by identifying the sorts of elites that existed in pre-capitalist empires and see how the creation and expansion of such empires generated conflicts that

2 Indeed that is an error Marx never made. Mann $(1986,1993)$ builds his historical analysis upon the ways in which the four forms of power that he identified are combined by various sorts of elite and popular actors and the institutions they inhabit. 
ultimately undermined those empires. ${ }^{3}$ By looking at the two most successful and long-lived such empires - the Roman and the Ottoman - we will be able to identify the sorts of domination such empires achieved and their limits. ${ }^{4}$

Ancient empires were dominated by military elites. The power of those elites was limited initially (1) by their need to recruit and retain soldiers who would be willing to fight for long years to conquer and rule other peoples and territories, and (2) by their need to enlist local elites in ruling the territories they conquered. Let us look at those two limits in turn, and then see how the structure of relations between military elites, their soldiers, and other elites at home and in the conquered territories was transformed by their struggles for resources and power, and how the flow of tribute to the center created additional elites that further complicated imperial politics.

\section{Recruiting and maintaining ancient armies}

Ancient empires, indeed all polities until the advances in transportation and communication of the eighteenth century, faced severe logistical limits in waging campaigns more than few days march from home. Their capacities for transporting provisions were highly limited, especially at sites not directly accessible by ships from sea. Animals, like humans, ate more in a week than they could carry. As a result, armies had to feed themselves and their animals by pillaging farms and urban storehouses as they fought. This restricted war and conquest to settled agricultural areas with surpluses capable of producing enough food to support both the farmers and the marauding troops. If an area produced too little food, then military seizures would cause the local population to starve and the area wouldn't yield a surplus for tribute in future years. That is why the boundaries of the Roman Empire ended at the sparsely populated Germanic woodlands in the northeast and at the desert south of its African territories. Similarly, deserts surrounded the Egyptian, Assyrian, Persian, Chinese and other ancient empires. Once armies had ventured more than a few days from home, they and their animals ran out of the food they had brought along and had to plunder their way forward or back home.

Athens and Rome exemplify the two principal ways ancient polities dealt with these logistical limits. Athens fought with citizen volunteers who stayed close to home. Athens and the other Greek cities were small, capable of fielding at best a few thousand citizen-soldiers. Greek battles were short. Hanson (1989) shows that the heavy armor worn by the Greeks, which minimized casualties, also exhausted their wearers in a few hours and the citizen-soldiers returned to their farms and

3 This section's discussion of the Roman Empire draws on Hopkins (2009), Mann (1986: chapter 9), Anderson (1974), Ste. Croix (1981), Wells (1984), and Greene (1986). The analysis of the Ottoman Empire draws on Barkey (2008).

4 Readers will note that I have little (one paragraph) to say about the Chinese empire, and that I conclude that empire was subject to limits as severe as those of the Roman and Ottoman empires. Of course scholarship advances in part by the incorporation of new cases into theory. I invite experts on China to examine if that (huge) case fits my model, and if not to explain how any differences matter for the arguments I advance about modern hegemons in comparison to ancient empires. 
cities, or to the ships that had brought them to other islands, literally at the end of the day. For that reason, the 'Athenian Empire' was relatively small-scale and only loosely integrated. Athens did not directly rule the peoples it had intimidated or defeated. Its empire was mainly an alliance of city-states that paid tribute to Athens under threat of attacks mounted by soldiers who could be transported by ships, engage in exemplary terrorism (such as the massacre of men and enslavement of women on Lesbos and Melos), and return home to Athens within days or weeks.

Rome overcame the demographic and logistical barriers that limited the size and revenues of the Athenian empire by offering rewards - a bonus equal to thirteen years pay upon retirement - sufficient to entice citizen farmers to enlist for long terms of service, which "increased from an unsustainable sixteen years, first to twenty and then to twenty-five years" (Hopkins, 2009: 193). While battle and disease ensured that many soldiers never lived to collect their bonus, the promise of enough money to allow soldiers to purchase a farm in Italy or a larger estate in the provinces upon retirement attracted recruits.

Rome's unprecedented ability to recruit large armies of long-term soldiers gave it a decisive advantage over all rivals. Roman soldiers, due to their long terms of service, had the time to be trained and to develop unit cohesion, creating a far more effective fighting force than those of earlier empires or contemporary enemies whose soldiers were not similarly professionalized. Roman generals did not have to worry about how to return their soldiers home at the end of battle. Since soldiers had made decades-long service commitments they could be stationed in garrisons in conquered territories. The constant presence of Roman soldiers raised the intimidation and supervision factors, allowing Rome to extract greater levels of tribute than previous empires. In addition, Rome's ability to man garrisons permanently because of soldiers' long terms of service made possible one of the great Roman innovations: its use of the army to construct roads, fortifications and provincial capitals. ${ }^{5}$

Rome's success in recruiting and retaining soldiers created a demographic crisis at home. The population of Roman farmers declined as more and more of them went into the army and remained in the conquered provinces after retirement because they had established ties (often including families) during their years garrisoned there, and because their retirement bonuses could buy more land outside of Italy. Roman farmers also were pushed to join the army and abandon farming because they couldn't compete with food produced by captured slaves on plantations in Italy or in the provinces. The demographic shortfall spread beyond Rome to the rest of Italy when Rome, unlike Athens, expanded its pool of soldiers by extending citizenship to conquered Italians in the 80s BCE (Hopkins, 2009: 182). By the turn of

5 The Persian (or Achaemenid) Empire exhibited elements of both the Athenian and Roman Empires. Like Rome, it was vast in scale. Like Athens, it relied on the occasional use of terror to convince its constituent parts to proclaim allegiance and pay tribute to the central ruler. Persian rule had very little effect on social relations in its 'conquered' lands and its boundaries expanded, contracted, and finally collapsed in response to the relative military skills of its rulers and their opponents (Wieshöfer, 2009). 
the millennium there were not enough Roman citizens to meet the army's manpower needs, and the Empire began to rely increasingly upon volunteers and mercenaries, recruited mostly from the conquered provinces. Some soldiers even were slaves who were granted eventual freedom in return for decades of military service.

The shift from citizen-soldiers to mercenaries initially empowered generals at the expense of the Senate and the remaining citizens. Mercenaries had no cultural or kinship link to Rome (although those developed later, as we will see in the next section) and fought for whomever paid them. Often Rome lacked the money to pay mercenaries and relied on generals to finance armies with loot from conquest. Hence mercenary armies were loyal to their generals rather than the civilian rulers of the Roman Empire. Generals could and did use the armies they controlled to make demands on Rome or to seize power for themselves. Coups and lesser interventions by generals in Roman politics were concentrated in the "late Republican period of imperial expansion," (Hopkins, 2009: 192) between the decline of citizen armies and before the creation of the Augustan settlement, which kept legions at the frontiers and weakened the hold individual generals and governors had over forces in each province by rapidly rotating them among offices. Those measures "depoliticized" the army (Hopkins, 2009: 193), eliminating the danger of coups though at the ultimate cost of weakening Rome's hold over provincial elites.

The decline of Rome's unprecedentedly successful citizen army destroyed the dual elite structure of the Republic, in which a citizen army with significant participatory rights in government counterbalanced the power of an "oligarchic aristocracy" (Hopkins, 2009: 179). Following a short interlude when a new elite of generals competed for power and resources with the oligarchy, a new imperial elite consolidated itself. Emperors were able to neutralize potential rivals in Rome but were limited by the growing autonomy of provincial elites and the need to accommodate the surviving Roman aristocracy, many of whom acquired mercantile interests. The number of elites thus shifted from two (aristocrats and citizen-soldiers) in the early Republic, to a different two (aristocrats and generals) in the late Republic, and to three in the Empire (emperors and their court, aristocrats, and provincial elites). It is inaccurate to consider merchants as a separate elite in any of these periods. Most of those involved in commerce, especially at the highest and most lucrative levels, were aristocrats or local elites, and even merchants who were neither remained largely dependent on access to tax revenues, loot, slaves or land that were controlled by generals in the late Republic or by emperors, aristocrats or local elites in the Empire.

\section{Provincial elites and the limits of Roman dominance}

Roman emperors after the Augustan settlement enjoyed, to use Michael Mann's terminology, "despotic powers [that were] virtually unlimited" (1986: 113). They were able to decide which men would hold high offices in the military and in the empire, and then shift those men around to prevent them from allying with factions in the Senate or combining at the frontiers to challenge imperial rule. 
Emperors could confiscate the estates of powerful aristocrats and even have such potential rivals for power killed. Yet each emperor had to maintain the support or at least the quiescence of most oligarchs, and each emperor needed to enrich loyalists at the court. Therefore the relative and absolute wealth of the aristocracy as a whole increased over most of the five hundred years of the Empire (31 BC-476 AD). In addition, emperors had to fund the dole to pacify the growing numbers of landless citizens whose farms had been bankrupted in competition with estates staffed with slaves. Thus, Rome was in a perpetual fiscal crisis once the rapid expansion of territory, population, and revenues came to an end by $25 \mathrm{BC}$ when the Empire reached the outer limits of lands it was profitable to conquer and hold.

At the same time as Roman and other ancient rulers had great despotic powers, they and their governments, like other pre-capitalist polities, lacked "infrastructural power" (Mann, 1986: 11). Rome's capacity to collect taxes or to affect social relations in the territories they conquered was minimal because the empire never was able to send Roman administrators to the conquered territories or to recruit local elites into a coherent Roman officialdom. This was primarily the consequence of political calculation by the imperial court, which feared to create an alternate power center by allowing generals or other officials to become permanent or capable administrators of provinces. Secondarily, the lack of infrastructural power also reflected the slowness of communication with distant provinces and the inability to gather detailed information on conquered peoples and their assets. As a result, Rome always had to rely on local elites, and the taxes they sent back to Rome never rose beyond the low level typical for central authorities in the pre-modern world. Agrarian productivity remained largely unchanged, ensuring that tax receipts could not rise with a growing economy. The empire mainly affected the conquered lands (after the initial destruction and looting and transportation of slaves back to Italy that accompanied conquest) by linking local elites to Rome culturally, legally, and through trade. The actual structure of political and economic relations within each conquered province remained largely unchanged.

Rome successfully pursued a number of strategies to integrate provincial elites with Rome: (1) employing the army to build roads to facilitate trade, (2) establishing an empire-wide system of law that protected all elites' accumulated wealth and allowed them to sell property or convey it to heirs, (3) ensuring that all elites, but only the elites, Roman and provincial, spoke and read Latin and received similar educations that focused on Latin language, rhetoric and literature (Mann, 1986: 313-17). These strategies and growing linguistic and cultural commonalities also facilitated the integration of Roman soldiers and officials into Latinized provincial elites. Thus, citizen-soldiers and lesser elites excluded from the Roman oligarchy could seek fortune and office in conquered territories. However, such integration also meant that imperial soldiers and administrators in the provinces found that they could maintain their privileges without support from the center. When the Empire came under pressure from barbarians in the fifth century provincial elites had little interest in fighting to protect the empire as opposed to their local positions. Indeed, the fall of the empire was a financial wash for such local elites: what 
they lost in exports to Italy (which while huge for Rome were modest for each province) they gained in not having to pay taxes to the center.

\section{The Ottoman solution to Rome's limits}

The extent of control the Ottomans were able to exert in their empire was not much greater than what the Romans had achieved 1500 years earlier. Like the Romans, "the Ottomans understood well the limits of their rule, in terms of both the geographical reach of their control and their limited manpower, and fashioned an empire that was based on organizational diversity... accepting of multiple systems of rule, multiple negotiated frontiers, laws and courts, forms of revenue management, and religious diversity" (Barkey, 2008: 70). Ottoman rulers, like Roman emperors, had the most control over the army. Soldiers, many of whom were recruited from out-groups (slaves, conquered and kidnapped Christian children, Greeks), were rewarded with grants of land that often were seized from hereditary aristocrats (Russian czars employed the same divide-and-conquer techniques).

Barkey characterizes the Ottoman strategy as "fiscalism," the effort to maximize revenues. In this the Ottoman Sultans were similar to other pre-capitalist imperial rulers in that they needed a constant stream of money to pay off their supporters, as well as to keep armies in the field to suppress opposition, repel rival powers, and to keep the whole enterprise going by expanding the empire's territory. The Ottomans, like the Romans, were felled mainly by internal conflicts and contradictions rather than external challenges. Sultans granted life-time tax farms in return for one-time payments in moments of fiscal crisis. Tax farmers, secure in their positions, were able to ally with merchants and landlords (especially those to whom they granted or sold tax sub-farms), creating what Barkey calls "regional governance regimes" that were highly resistant to Sultans' efforts to play elites off against one another. This worsened the fiscal crisis, and also provided a basis for demands for autonomy and independence in peripheral areas, especially the Balkans.

\section{Domination not hegemony}

Rome achieved total military domination in its empire, at least until it was attacked by barbarians in the fifth century. After the defeat of Hannibal in 202 BC no military power was able to directly challenge Rome. Rebellions from slaves and conquered peoples were crushed. The use of extreme exemplary terrorism (the crucifixion of thousands of defeated slaves at the end of the Third Servile War in 73-71 BC) led to an abrupt end of such uprisings. The Augustan settlement ended (with only two exceptions) the military coups that plagued the last years of the Republic. Other empires, including the Ottomans, were less successful in destroying military rivals and faced continuing challenges from neighboring polities even when they were able to subdue all challenges within their existing territories.

All these empires, including Rome, were able to achieve only limited political dominance despite their military supremacy. Rome had to work with and through existing elites in the conquered lands outside of Italy. Beyond extracting taxes, its 
main influence was in personnel, through inserting Italians into the local elites, rather than upon structure. Similarly, its cultural influence was limited to the elites. Roman law meant little to the lives of common people, and Latin language and culture did not penetrate deeply. Finally, Rome's effect on the economy was circumscribed. As we saw, it had little influence on economic relations outside Italy, except for extracting taxes and giving elites the opportunity to trade local products for Roman luxury goods and to meet tax demands. Within Italy the empire decimated independent farmers in favor of plantations operated by slaves.

The Ottomans used military force to insert tax collectors into its conquered provinces, while ceding rule in other realms to existing local elites. Ottoman political and economic leverage was further undercut when tax farmers bought land and establish links to local landlords and merchants, creating regional economies autonomous from the Ottomans. The new Ottoman economic elites differed from local elites in the Roman Empire in that they somewhat modernized their local economies, especially in the Balkans (Barkey, 2008: chapter 7). Balkan economic development reflected Ottoman infrastructural weakness and inability to penetrate provincial economies in any way besides tax collection backed by military force. Balkan merchants had an advantage over the merchants of ancient empires in that they could trade with counterparts outside the empire, some of whom by the last centuries of Ottoman rule already were part of capitalist economies.

Throughout their centuries of conquest and imperial rule, Rome and the Ottomans remained overwhelmingly dependent on military force. They never was able to establish political or economic mechanisms that exerted control that was substantially deeper than what their armies had been able to accomplish at the moment when they defeated and occupied its non-Italian or non-Turkic territories.

The army provided the primary political and organizational dynamic of both the Roman and Ottoman Empires. The creation, expansion and maintenance of both empires depended on their armies' capacities to recruit, motivate, and keep soldiers. At the same time, armies and their generals were threats to rulers whom they could overthrow, and to the old elites at the core of each empire with whom they competed for resources. Rulers in both empires found ways to undermine the armies' and their generals' capacities to challenge the regime. However, those stratagems all had the effect of increasing the power and autonomy of provincial elites. For rulers of pre-capitalist empires there was no other strategy but the trade-off between empowering armies and empowering local elites. Aristocrats from the original core of the empire never could be molded into a bureaucracy since their independent base in landed estates and their kin and other ties held the threat they could coalesce into potential challengers to the imperial court. For that reason, rulers always sought to weaken and divide hereditary aristocracies, a strategy that was totally incompatible with recruiting them into an effective imperial bureaucracy.

Nor could merchants be used to bypass the army or local elites to extract resources from conquered territories. In the absence of either capitalism or of a stable bureaucracy, rulers were unable to transform or penetrate local economies in ways that would allow rulers to extract more than an army could force 
local elites to pay. To the extent that the army was weakened or stationed permanently in the provinces (or recruited from provincials) the leverage to extract taxes declined further.

Chinese emperors did create a corps of imperial officials in an effort to counterbalance the army. However, those officials were recruited mainly from provincial gentry. A gentry-official alliance allowed local elites to control army garrisons. Thus, beneath the veneer of a common Confucian culture and national examination for entry into a 'bureaucracy,' officials and military officers were linked far more tightly to local landlords than to the imperial court or generals. Chinese emperors had little capacity to augment their own power or to draw resources to the center by playing army and officials against each other since both already were in essence parts of local elites. Local politics and economies were little affected by dynastic changes. Indeed the frequent shifts in the location of the imperial capital reveal the weakness of any 'center' in an empire whose rulers were replaced at intervals far more frequent than in the Roman or Ottoman Empires. China did not overcome the limits of central power in ancient empires.

\section{What made modern empires different}

Modern empires had very different elite structures than ancient empires or the Ottoman Empire, which were characterized by two domestic elites (aristocrats/landowners and citizen-soldiers/generals/emperors) at home, and an additional provincial elite in the conquered lands that was kept in line largely by military force. Modern empires were shaped and managed by two elites - capitalists and state officials - that were fundamentally different from the elites of ancient empires or the Ottoman Empire, even as those modern elites were sustained in their imperial endeavors by their home country's military power. In empires and colonies where older elites - most often landed aristocrats and military officers - played key roles along with capitalists and civilian state officials those older elites differed fundamentally from the armed men and landowners of pre-capitalist empires because (1) they wielded much greater infrastructural power than their ancient counterparts, and (2) they had to share imperial power with modern capitalists and state officials.

Capitalists, unlike merchants in ancient empires, did not have to wait until imperial armies had conquered new lands to control trade routes and extract revenues from foreign lands. Capitalists enjoyed a high degree of autonomy for two reasons. First, unlike ancient or Ottoman merchants, they were genuinely separate elites at home because they had independent organizational capacities to appropriate resources from non-elites. Second they were able to engage in commerce with capitalists from other polities, which gave them further leverage at home.

State officials in modern empires differed from their ancient and Ottoman counterparts in that they could deploy strong non-military organizational capacities that gave them "infrastructural power" (Mann, 1986: 11) able to penetrate conquered societies. This gave modern imperial administrators means in addition to 


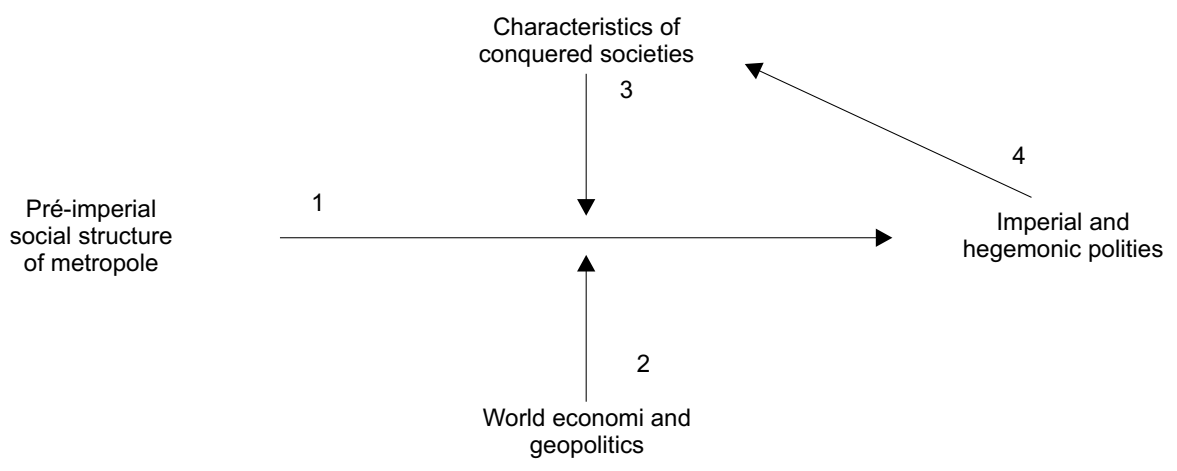

Figure 1 Causal relations in models of hegemony and imperialism

the threat of force that they could use to manipulate local elites, and in some cases to interact with and extract resources directly from the mass of subjects in the lands they conquered.

Capitalists and state officials had varying effects on metropoles and colonies, and on the place of their empire in the world system. Those variations, across time and space, had little to do with the resources and capacities those elites initially commanded as they began their imperial conquests and was determined mainly by three factors: the number of elites, their location, and the overall structure of their relations.

- Number: imperialism created new elites at home and in the colonies. The number of elites in the pre-imperial metropole, their identities, and the structure of their interrelations shaped the number and structure of elites the European powers installed in the lands they conquered. ${ }^{6}$ The mere addition of those new elites to the existing number of elites disrupted existing elite relations and prevented the stalemates between two metropolitan and two provincial elites that characterized the Roman and Ottoman empires. Multiple elites opened the possibility of more complex dynamics in modern empires.

- Location: some colonial elites became permanent settlers in colonies, while others left the metropole only temporarily or moved among colonies, and others were involved in colonial rule and exploitation without ever leaving home. As we will see below, settlers enjoyed more autonomy but also had less influence over metropolitan politics than officials and capitalists who were only temporarily based in colonies. Empires with settler colonies had very different dynamics than those empires without such colonies, although the

6 This is one of the great insights we can gain from Steinmetz $(2007 ; 2008)$, who is discussed in the following sections of this article. 
very different trajectories of the Spanish and British empires remind us that this factor exerted its causal force in interaction with the number and structure of relations among elites.

- Structure: multiple elites in different, and often shifting, locations made possible varying and changing alliances among elites. Those alliances, in turn, shaped the elite conflicts that then eliminated elites, created new elites, changed the strategic meanings of each elite's location, and altered the structure of elite relations, which in turn opened new possibilities of alliance and conflict.

\section{How to study modern empires and hegemons}

My working hypothesis is that contingent chains of elite conflict and structural change determined the viability of modern empires, their relative geopolitical and economic standing, whether they became hegemons, and how long and in what form their hegemony endured. These chains began in the pre-imperial social structures of metropoles, and were affected by the characteristics of the societies they conquered and by the nature of the world economy and geopolitics, which was different at the particular historical moments when each polity was creating, sustaining or losing its empire or hegemony.

Different authors focus their work on particular points along those contingent chains, or highlight one side or the other of interactions between metropolitan and colonial social structures. Figure 1 presents the four main causal relationships highlighted in various models.

World systems theory is best at explaining how the cycles of the world system open and close opportunities for empire and hegemony (arrow \#2 in figure 1), but has little to say about internal characteristics, such as elite structure, that determined which polities took advantage of those openings to achieve empire or hegemony. As a result, empires and hegemons enter Wallerstein and Arrighi's world histories only at the point when they vied for hegemony, which leaves those polities' earlier centuries of conflict and structural change largely unexamined. Similarly, the hegemons drop from the story when their successor emerges triumphant, and so these authors do not examine the dynamics of the former hegemons, empires or spheres of influence after they fall from world leadership. ${ }^{7}$

World systems analyses, because they operate at the most macroscopic level, do not attempt to explain a single polity's variations in imperial strategy across or even within colonies. As a result, the complexities and internal elite conflicts within empires and hegemons fall out of world systems analyses, and there then is no basis to explain how some colonial elites affected metropolitan politics while others did not, nor the varying levels of autonomy enjoyed by colonial elites.

7 Wallerstein, in the Preface to his fourth volume of The Modern World System (2011 [1974]), offers a concise and elegant explanation of why and when different conceptual elements enter into his historical analysis. 


\begin{tabular}{|c|c|c|c|}
\hline & & \multicolumn{2}{|c|}{$\begin{array}{l}\text { Colonial elites' level of autonomy } \\
\text { from metropolitan officials }\end{array}$} \\
\hline & & High & Low \\
\hline \multirow{2}{*}{$\begin{array}{l}\text { Colonial elites' Influence } \\
\text { on metropole's economy } \\
\text { and/or politics colonies }\end{array}$} & High & $\begin{array}{l}\text { Dutch colonies } \\
\text { Spanish American colonies } \\
\text { French colonies }\end{array}$ & $\begin{array}{l}\text { British India \& other non-settler } \\
\text { colonies } \\
\text { US formal and informal colonies }\end{array}$ \\
\hline & Low & $\begin{array}{l}\text { British settler colonies } \\
\text { German } \\
\text { Ancient Roman provinces } \\
\text { Ottoman provinces }\end{array}$ & $\begin{array}{l}\text { Napoleonic empire } \\
\text { Nazi empire }\end{array}$ \\
\hline
\end{tabular}

Figure 2 Situates ancient and modern empires along those two dimensions

Arrighi and Wallerstein do not regard that as a shortcoming, since for them it is the dynamics of the world system not internal elite conflicts that determine imperial policy.

We need to look elsewhere for inspiration and guidance if we want to follow the contingent chains of conflict that lead from pre-imperial polities to the creation, and eventual destruction of empires and hegemons. We will not find much help from the vast literature on imperialism, underdevelopment, and dependent development, which focuses almost exclusively on arrow \#4. My contention is that a model of imperial and hegemonic dynamics that seeks to explain when and how polities achieve and lose hegemony must address the causal relationships expressed by arrows 1, 2 and 3, though not arrow \#4. Three scholars, George Steinmetz (2007; 2008), James Mahoney (2010), and Julian Go (2011) address the lacunae of world systems theory and the literature on development in different though complementary ways. Steinmetz addresses mainly arrow \#1, and Mahoney's model melds the causal factors represented by arrows \#1 and \#3 in Figure 1. Go makes the crucial point that the causal relations encompassed by all four arrows operate differently in each empire's eras of "hegemonic assent," "hegemonic maturity," and "competition/decline." These three authors share a focus on empires, not hegemons (although the British and U.S. empires that are Go's focus for a time did achieve hegemony as well), and each of these authors offers an historical analysis of specific empires, not a theory of empires in general. However, as we develop a typology of empires we will be able to see the ways in which their conclusions can be generalized beyond their particular cases.

\section{Types of modern empires}

An empire, in Go's (2011: 7) definition, is "a sociopolitical formation wherein a central political authority... exercises unequal influence and power over the political (and in effect sociopolitical) processes of a subordinate society, peoples, or 
space." However, that power is not exercised entirely from a polity's center. We saw above how in pre-capitalist empires colonial elites operated with a high degree of autonomy from metropoltian elites. Modern empires varied in the extent to which colonial elites were autonomous from metropolitan officials. Similarly, while colonial elites in ancient empires had little effect on the metropole's economy or politics, some modern colonial elites have had a strong influence over the metropole.

The empires in each quadrant had somewhat different dynamics. Yet, the insights Steinmetz, Mahoney, and Go achieve by focusing on a particular empire do have implications for the cases in the other quadrants, as well as for other empires structurally similar to the ones they study. We will begin with the lower left quadrant, the empires whose colonial elites enjoyed the most autonomy from the metropole, and also had the least influence on metropolitan economy and politics. This will allow us, thanks mainly to Steinmetz's analysis of German colonies, to understand the essential differences between ancient and modern colonial elites. Next, we will focus on the upper left quadrant, drawing on Mahoney's comparisons among Spanish American colonies to see how colonial elites can affect elite relations in the metropole even as they retain a high degree of autonomy.

We then will look at two cases of almost pure colonial exploitation, the Napoleonic and Nazi European empires in the lower right quadrant. While geopolitical forces (i.e. defeat in war) quickly felled both empires, had they endured both Napoleon and Hitler's empires would have transformed the structure of elite relations in the metropole. Early signs of those changes provide a basis to speculate on the sort of imperial polity that would have developed, and to compare that structure and the dynamics of that quadrant to those in the upper right quadrant.

The three polities in the upper right quadrant are the three capitalist hegemons of the last three centuries. I will reserve detailed analysis of those three cases, and of the Spanish and French empires, for the rest of my forthcoming book. My goal, in the concluding section of this article, is to contrast hegemons to the other cases and to offer a series of hypotheses about how hegemonic social structure and the resulting dynamic of elite conflict differ from the other three types.

\section{Autonomous colonial elites}

How did modern colonial elites attain autonomy, and what did they do with that autonomy? Steinmetz, by studying German colonies, is able to examine cases where conflicts among colonial elites could play out without the confounding effects of heavy interventions from central authorities or capitalists based in the metropole. This allows him to reveal and analyze an essential dynamic of elite relations in modern colonies.

What does Steinmetz find? First, colonial officials didn't arrive in conquered lands as individuals. Rather, they came as representatives of elites transplanted from home and maintained their distinct identities in the colonies. The three principal German elites, "the nobility, the propertied bourgeoisie, and the Bildungsbürgertum (i.e., the educated middle class)," (2008: 597) arrived in the colonies with distinct 
forms of capital that they deployed to gain control over the German colonial government. The main terrain of struggle was over "native policy." Each elite made claims to "ethnographic expertise" based on the sort of cultural capital they brought to the colonies from Germany.

Steinmetz shows how "Drawn-out contests between different fractions of a splintered dominant class may prevent a field from being settled while enhancing its autonomy, as field-specific modes of action become more systematic and clearly defined" (2008: 600), and provide a basis for colonial elites, both individually and collectively, to "enhance their autonomy from the metropolitan state over time" (2008: 591-92). In other words, while the three German elites fought with each other over how to deal with natives, they fought on the basis of expert knowledge, which they claimed was refined through first-hand experience in ruling over the particular natives of the colonies they inhabited. As each elite asserted expert knowledge, the three colonial elites collectively were able to distinguish themselves ever more decisively from their putative superiors, and the metropolitan elites that lobbied officials back in Berlin, and from elites in other colonies who, because they ruled different sorts of natives, had different expertise that could not be automatically transferred to another colony. The colonial elites used their claims of expertise to prevent metropolitan Germans from interfering in colonial policies directly or from exerting indirect influence by allying with one colonial elite against the others in return for policy decisions or a share of the colonial spoils. This was evidenced in the growing capacity of colonial officials to take actions that were inimical to the interests of metropolitan capitalists, or even to the central German government's geopolitical interests. It also is demonstrated by the very different native policies officials pursued in Southwest Africa, Samoa and Qingdao, differences that can't be derived from economic or geopolitical considerations.

Steinmetz's German colonial officials achieved autonomy by very different mechanisms than ancient colonial elites or than British settler colonists, the other colonial elites that share the same cell in figure 2. Ancient elites gained autonomy mainly as a result of central officials' lack of capacity. By contrast, the German state had the resources and infrastructural capacity to monitor what their agents were doing in the colonies and to intervene to force a change in policy. Yet, the central state did not utilize that capacity, and metropolitan elites did not exert enough pressure to make the state do so.

Similarly, British settler colonists did not win their autonomy due to a general lack of capacity on the part of metropolitan officials. Britain's non-settler colonies, above all India, are in the opposite quadrant in figure 2 from British America even though all were part of a single empire. While Britain's overall imperial capacity to monitor and project force was common to the settler and non-settler colonies, ${ }^{8}$

8 The British Empire's capacities did differ over time, as Go (2011) reminds us. However, the American colonies gained independence in the same years as the British East India Company was subordinated to the state, and Canada, Australia and New Zealand had their greatest leverage at the height of British hegemony. To solve that seeming conundrum we need to analyze the dynamics of hegemons. 
those two groups of possessions differed fundamentally in the numbers and self-organization of Britons in each colony. In India and the other non-settler colonies, Britons were few and remained highly dependent on metropolitan power and capital of all varieties.

American and other British settler colonial elites, unlike German colonial administrators or Britons in India, did not plan to return home and therefore assumed identities based on their American social positions and the sorts of capital they could accumulate in the colonies. ${ }^{9}$ The growing numbers of British settlers in America built their own organizational capacities that progressively lowered their governmental, military and economic dependence on Britain and, as the 1776 Revolution demonstrated, gave them the ability to subvert and challenge officials shipped over from the metropole. In the nineteenth century, settlers in Canada, Australia and New Zealand achieved a high degree of autonomy and got major concessions from Britain without having to mount their own wars of independence.

British settler colonists strengthened their autonomy by weakening two sources of leverage that European metropolitan governments exerted in other colonies. First, as British settlers created their own governments and were able to limit the number of officials appointed by the crown rather than chosen by the settlers themselves, Britain lost the ability to play settlers off against each other in the competition for lucrative offices as the Spanish and French were able to do at first in their colonies (Elliott, 2006: 237-45). As the Spanish and French crowns sold colonial offices, they too lost that leverage and colonial elites won increasing autonomy. Second, settlers also reduced their dependence on the British state and its armed forces by exterminating rather than subjugating the natives. Indeed, the British recognized this point of pressure by at times encouraging Indian attacks on defiant American colonists, and Indian policy became a key issue for American revolutionaries. As long as settlers did not become dependent on native labor Britain remained limited in the leverage it could gain from native attacks. New Zealanders lost little autonomy when they had to call on British troops to defeat Maori rebellions, while British settlers in Southern Africa were limited in their assertions of autonomy by economies organized on the basis of cheap native labor. ${ }^{10}$

The German state was hardly limited by either factor. German colonial offices were filled from Berlin, and German colonies were populated by and depended overwhelmingly on the labor of natives. As Steinmetz shows, the genocide against

9 Breen (2004) shows how colonial Americans' growing wealth created a culture of consumerism that allowed boycotts of British goods in the 1770s to create an American identity, transcending both local differences and their status as British subjects, that became a foundation of popular resistance. The sort of cultural capital Breen describes is very different from the expertise Steinmetz analyzes; however, both American consumerism and German colonial native policy contrasted local knowledge and practices to the uninformed dictates or unjust demands of metropolitan officials.

10 In the next section we will see that Mahoney (2010) offers a more complex, multi-step model of the relationship between the size of the indigenous population and the form of colonial rule in Spanish America. 
natives in Southwest Africa was a consequence rather than a cause of colonial officials' autonomy. So why were German metropolitan elites unable or unwilling to affect colonial politics, or to use their control over colonial offices or the threat of native rebellion to manipulate or discipline colonial elites? After all, the central agencies the metropolitan governments in London and Paris (and Brussels, Rome and Washington) created to manage their colonies all claimed expertise in managing natives. Decades later, the Nazis overruled diplomats, military officers and businessmen to set 'native policy' for the conquered lands of Europe, and enforced tight control over German officials in those lands.

Steinmetz answers the question by showing how the long-running dynamic of conflict among German colonial elites deepened the organizational as well as ideological bases for their claims to autonomous expertise. That autonomy was furthered strengthened because German colonial elites were unable, and for the most part did not attempt, to exert leverage back in the metropole in the elite conflicts there. German colonial elites, in other words, deepened their autonomy by isolating themselves from metropolitan interests. That isolation was, in part, a matter of scale: the German colonies were hardly profitable and meant little for the state budget or for the interests of German capitalists at home. Colonial offices and revenues were insignificant in the political conflicts and economic calculations of metropolitan German elites. In contrast, American colonies were of such importance as a market for British manufacturers that they intervened with their Parliamentary representatives to repeal the Stamp Act (Elliott, 2006: 316), and as we will see in the next section Spain's American colonies were of vital importance for the fiscal viability of the Hapsburg monarchy and for the particular interests of court factions and metropolitan elites in Spain, and French colonies while not vital for state finances were significant revenue sources for particular elites.

German colonies also were insignificant geopolitically. German colonial officials had little to offer militarily or economically to elites back home. Nor did the expertise in native policy which colonial elites claimed give them any special leverage or legitimacy in metropolitan politics. Germany's colonial possessions mattered at home mainly for prestige. Unlike, the colonies or quasi-colonies of Britain, France, Spain, the Netherlands, Portugal, or later the United States, German colonies did not affect elite relations back home.

The elites of British settler and German colonies attained their autonomy through the active creation of cultural capital and organizational capacities in the colonies. While the mechanisms of creation and the sorts of capital differed, both sets of colonial elites used them to achieve high levels of autonomy. Unlike provincial elites in ancient empires, their ability to deflect or flout demands from the metropole was not a mere reflection of the center's weak capacities. The ways in which the colonial elites in this quadrant maintained their autonomy meant that they also had little influence over the metropole. The effect of that absence, on the dynamics of the entire empire, can best be understood in comparison to the empires in the upper half of figure 2 whose colonies did affect the metropole's political economy. 


\section{Colonial elites in the metropole}

Valuable and geopolitically crucial colonies captured the interest, and provoked the intervention, of elites back home. Yet, in the Spanish and French empires, listed in the upper-left quadrant of figure 2, colonial elites retained a high degree of autonomy even as they profoundly affected social relations back in the metropole. How was that accomplished?

Some of the colonies seized by the French and Spanish were immensely valuable, and the riches that could be taken from them were quickly apparent to elites in the metropole. Metropolitan elites vied with one another to control colonies by planting their representatives in offices and on landed estates in the conquered lands. The multiple elites in metropolitan Spain and France did not each create a distinct colonial elite in their image, differentiated by forms of cultural capital (as in the German colonies) or by distinct organizational apparatuses. Rather, Spanish and French kings, great nobles, clerics and state officials each granted a welter of concessions to men journeying to the colonies in return for up-front payments or promised shares of future revenues. While the monarchs were, at least in theory, the ultimate arbiters of conflicting colonial claims, kings often ceded that power or specific colonial concessions to metropolitan elites in return for revenues or domestic political support, further undermining metropolitan leverage over colonial elites.

High levels of conflict among metropolitan elites were a necessary but not sufficient condition for colonial elites to achieve autonomy from the metropole. As Mahoney (2010) demonstrates through his comparison of Spanish American colonies, the colonies' pre-conquest social structure shaped colonial elites' organizational capacities and thereby determined whether they could sustain their autonomy against efforts by monarchs and other metropolitan elites to reassert (or often to assert for the first time) control over colonial officials and resources.

Mahoney finds that Spanish American colonial elites were more unified in territories where they were able to plant themselves in rich, complex and densely settled pre-colonial societies. Colonial elites magnified their control over indigenous peoples where they could appropriate already-existing complex systems of rule and where the conquered peoples were populous enough to supply sufficient labor to man plantations and mines. In those colonies, Spanish conquistadors were able to establish what Mahoney labels "higher levels" of "mercantilist colonialism." Mahoney's detailed histories of each colony show that where a high level of mercantile colonialism was established there was a tight linkage, which in practice amounted to a fusion, of officials, clerics, landlords and merchants. In territories (such as what later became the southern cone countries of Chile, Argentina and Uruguay) where indigenous peoples were few and scattered and did not have a complex polity, Spanish conquistadors were unable to extract enough resources to sustain themselves in significant numbers. In those territories, the colonial elites had little leverage over the crown and other metropolitan elites, and in the eighteenth century the Spanish crown was able to insert new elites that competed with and subordinated the earlier settlers. 
Mahoney identifies a different mechanism for Spanish American elite autonomy than does Steinmetz for German colonial elites. However those mechanisms reflect the particular elite structures in the two metropoles and the two empires' organizational capacities. German colonial elites did not have to leverage the political infrastructures of the lands they conquered because they arrived with far more sophisticated (bureaucratized) organizations than did the Spanish conquistadors, possessed far better communications technologies to communicate with one another and back to the metropole, and wielded far more deadly military technology in the nineteenth century than the Spanish did in their centuries of American rule (in the oft-quoted words of the mediocre British poet Hilair Belloc, "Whatever happens, we have got/ The Maxim gun, and they have not").

Beyond the different capacities German and Spanish elites brought to their colonies, they arrived holding different positions in the overall elite structure of the two empires. German colonists, as Steinmetz demonstrates, came from already distinct metropolitan elites, defined more by their sort of cultural capital than by a matrix of structural relations between colonial offices and metropolitan institutions. In contrast, Spanish colonists held offices and controlled encomiendas and other concessions that overlapped and brought them into conflicts with one another. As long as Spanish colonial elites had to appeal to the Habsburg monarchs, or to other elites to whom the crown had ceded colonial authority, to clarify and guarantee their jurisdictions, they remained handicapped in their assertions of autonomy (Elliott, 2006: 353-68 and passim). However, where there were rich and complex indigenous social organizations that Spanish conquistadors could appropriate, colonial elites were able to rapidly structure themselves in ways that reduced their organizational and ideological dependence on their metropolitan patrons. In terms of winning autonomy, the conquistadors' social appropriations served the same purpose as the more gradual German colonial elites' construction of expertise and British settler colonists' creation of national identities and institutions (above all representative assemblies). Similarly, French colonial elites unified themselves and guaranteed their autonomy by building slave institutions on islands where they had exterminated the indigenous population.

The structures of rule created in the first moment of colonization mattered for subsequent economic development ${ }^{11}$ as well as for the room imperial rulers back in the metropolitan capital enjoyed to restructure colonial rule. The complexity of metropolitan elite relations in Spain and France in the sixteenth through eighteenth centuries meant that colonial elites often had multiple patrons whom they could play off against each other for further autonomy. As the wealth produced in the colonies increased, metropolitan elites themselves gained an advantage in their struggles with one another to the extent that they could win the (at least temporary)

11 Mahoney's goal in his book is to explain post-independence economic and social development. He is less concerned with the effects of colonial rule on the metropole. However, I have taken advantage of his prodigious historical research and the structure of his argument to draw conclusions about the metropole. 


\begin{tabular}{|c|c|c|c|c|c|c|c|}
\hline \multirow{2}{*}{$\begin{array}{l}\text { Colonies autonomy } \\
\text { influence }\end{array}$} & \multicolumn{5}{|c|}{ Five mechanisms } & \multicolumn{2}{|c|}{$\begin{array}{l}\text { Two outcomes for colonial } \\
\text { elites on metropole }\end{array}$} \\
\hline & $M$ & 1 & C & $\mathrm{N}$ & s & & \\
\hline German & 0 & 0 & 1 & 0 & 0 & 1 & 0 \\
\hline French & 1 & 0 & 0 & 0 & 1 & 1 & 1 \\
\hline Bristish settler & 0 & 0 & 0 & 1 & 0 & 1 & 0 \\
\hline $\begin{array}{l}\text { British settler } \\
\text { (American South) }\end{array}$ & 0 & 0 & 0 & 1 & 1 & 1 & 0 \\
\hline $\begin{array}{l}\text { Spanish strong } \\
\text { mercantile }\end{array}$ & 1 & 1 & 0 & 0 & 0 & 1 & 1 \\
\hline $\begin{array}{l}\text { Spanish weak } \\
\text { mercantile }\end{array}$ & 1 & 0 & 0 & 0 & 0 & 0 & 0 \\
\hline
\end{tabular}

Figure 3 Boolean truth table of colonial elite autonomy and metropolitan influence

$\mathrm{M}=$ multiple metropolitan elites in conflict; $\mathrm{I}=$ complex indigenous structures appropriated by colonizers;

$\mathrm{C}=$ colonial elites create cultural capital; $\mathrm{N}=$ settlers create national identity; $\mathrm{S}=$ settlers create slave institutions

loyalty and financial support of colonial elites. This, of course, gave colonial elites greater leverage in their negotiations with monarchs and other metropolitan elites for autonomy and to keep a larger share of the revenues they generated. The colonies with less dense indigenous societies and weak colonial elites contributed little and had little influence on the metropole.

Colonial elites' deals with metropolitan elites were often significant, and at times proved decisive, in the outcomes of French and Spanish metropolitan elite conflicts. That is how colonial elites affected the structure of elite relations for the empires in this quadrant. The sort of transformation was very different from that which occurred in hegemons (discussed below). The Spanish and ancien regime French empires did not create new metropolitan elites; instead they affected the balance of power among existing elites.

How did colonial elites' interference in metropolitan elite conflicts matter for Spain and France's ability to compete geopolitically and in the world economy? The stability and autonomy of elites in Spanish and French colonies, while initially made possible by elite instability in the metropoles, then helped to sustain and deepen elite conflicts in France and Spain. In that sense, the French and Spanish metropoles were uniquely disordered among the empires and hegemons discussed in this article and represented in figure 2.

Colonial elite unity and metropolitan elite disorder weakened Spain and France's geopolitical positions. While all the great powers attempted to seize one another's colonies from the initial colonization of American until the Congress of Vienna, Spain and France were uniquely vulnerable because their especially autonomous colonial elites at times were able to ally, or threaten to ally, with rival powers against their nominal rulers, seeking better terms from a new master or greater concessions from their current monarch. Britain had a similar vulnerability, but only with their settler colonies, most notably the Americans whose victory was 
sealed with French support. German's colonies were not vulnerable in the same way, since Britain acquiesced in and at times facilitated Germany's colonial acquisitions (Porter, 1984: 101-11 and passim). This reduced German colonial elites' leverage over the state, and therefore the extent to which those elites or the fate of their colonies entered into German metropolitan politics. analysis.

Let's summarize our findings in this and the previous section with a Boolean

We can see that colonial elites were able to attain autonomy through various mechanisms. Any one mechanism was enough to attain autonomy: German colonial elites' cultural capital of expertise in native management, the slave institutions created by French colonists in the Caribbean and British settlers in the southern colonies, the national identities created by British settler colonists, or the complex indigenous institutions that Spanish conquistadors appropriated to build their own unified social networks and system of rule. Colonial elites were unable to exercise autonomy only in those Spanish colonies where natives were scattered and complex social institutions did not exist, and as we will see below in the Napoleonic and Nazi European empires and in hegemons' non-settler colonies. However, colonial autonomy did not translate automatically into influence in the metropole. Only where the metropolitan polity was characterized by multiple elites in active conflict did colonial elites affect those conflicts and thereby shape metropolitan social structure.

\section{Pure imperial exploitation}

Napoleon and Hitler's European empires, like Spain's American empire, conquered existing societies with dense populations and complex indigenous social institutions. Like the conquistadors, Napoleon and Hitler's armies, especially the latter, relied on local collaborators to raise revenues, corral strategic materials and manufactured goods, and in the case of the Nazis to round up Jews for extermination. Napoleon differed from Hitler in his ambition to transform the societies he conquered, and obviously in the goals he had for his conquered dominions. Yet, the dense and complex local societies did not provide an opening for the Napoleonic or Nazi elites sent to administer and loot conquered lands to win autonomy. Those two empires stand as polar opposites to the Spanish empire, or to France's non-European colonies, even during the Napoleonic era. ${ }^{12}$

The key difference between the Napoleonic and Nazi empires and all others lies in their extreme dominance by a single military or military-party elite in the metropole. That single elite was able to exercise tight control over the men they sent to rule and exploit the conquered lands. As a result, neither capitalists nor civilian state officials in those two empires were able to gain independent access to conquered lands. This weakened the leverage of capitalists and state officials both at home and in the conquered lands. Nor could the 'colonial' elites of the Napoleonic

12 The discussion of the Nazi empire in this section relies upon Mazower (2008) and Aly (2005). 
and Nazi empires exploit divisions among metropolitan elites in the way that Spanish American elites did. Napoleon had built on the achievements of the revolutionary governments that preceded his in suppressing the aristocracy and subordinating capitalists, while the Nazi party achieved tight control over the pre-Nazi civil service, intimidated the military, and confined capitalists and landowners to an ever more marginal role. Mann (2004; see also Riley, 2004) notes that after the war landowners were eliminated as a significant class in Germany, and attributes that to Nazi policies. He argues that had the Nazis remained in power the existing capitalist class would have met the same fate.

The military elite of the Napoleonic Empire and the Nazi party were on paths to becoming single ruling elites, forcing capitalists, landowners, and civilian state officials into subordinate positions that would have left them somewhat privileged but not elites in the sense of having independent organizational capacities to extract resources and the power and autonomy that went with such capacities. The high administrative capacities of both the Napoleonic and Nazi regimes ensured that the officials and soldiers sent to rule conquered European lands remained under close surveillance and tight supervision, unlike the ancient Rome or Ottoman colonial elites. French revolutionary ideology and Nazi racial doctrines also made occupying elites loath to establish ties with local conquered elites that could have provided a basis for resistance against metropolitan edicts. Napoleon and Hitler's defeats cut off that process. The sudden elimination of Napoleon's army and the Nazi party created structural room for the reemergence of capitalists and new state elites in both countries. A new corps of state officials and a new capitalist elite in post-Napoleonic France became the central actors in sustaining and expanding France's non-European empire in the nineteenth and twentieth centuries.

Would a single elite, organized within the Napoleonic state or the Nazi party have been able to sustain a monopoly on power in the metropole and the conquered lands if Napoleon and Hitler had won their wars? The answer for France seems almost certainly no. Napoleon was far less able than Hitler to suppress resistance in conquered lands, and the need to accommodate local interests would have provided a basis for the French military elite in each conquered territory to develop interests and organizational capacities separate from the metropolitan ruling elite. The Nazi's unprecedented success, and unprecedented capacity and willingness to use massive terror, ensured little resistance in its empire, blocking a potential basis for division between party officials in Germany and abroad. The Nazi empire, had it survived, would have become the only empire with a single elite, eliminating elite conflict as a basis for structural change in the foreseeable future. In that way the Nazi empire was unique in world history, and on its way to creating an actual 'end of history' in its domains. Yet, we need to remember that empires never exist in a vacuum. Unlike, the ancient empires, which were bordered by deserts and sparsely inhabited woodlands, the Nazi empire was part of the modern world. The war-making which created it also inevitably brought it into contact with the forces that destroyed it. Nor could the Nazi regime make peace with its enemies, since continual conquest was necessary to bring in enough loot to sustain the German economy and to sustain the regime's ideological hegemony at home. As a pure empire without elite conflict, the 
Nazi regime was a short-lived anomaly, indicative of how the elite structure of metropoles remained the ultimate limitation on colonial elites' autonomy and on the ways in which they could affect metropolitan politics and economics.

\section{How hegemons are different}

My goal is to explain why particular polities have gained or lost (or never managed to achieve) geopolitical and economic advantage over all other societies in the world. I am not trying to explain why one polity merely held first place, became wealthy, or a military 'great power.' Rather, I want to understand how one polity achieved and held leverage that allowed it to shape the operations of the world capitalist system and geopolitical order to its singular advantage. That is what I mean by hegemony.

Hegemony is not just a quantitative or qualitative edge over rivals. And it is not just leadership in the sense of taking first place. Rather, hegemony is institutionalized - in networks of finance, trade, and production, and in geopolitical alliances and the capacity to project military power throughout the world - to reinforce and further expand the hegemon's advantage over rivals. Thus, a polity can be said to be hegemonic only as long as it is able to enforce a system of geo-political and economic relations that advantages it over all other polities.

Hegemons, thus, differ from empires in that their power extends beyond their formal and informal territorial possessions to encompass the entire world, or, in the case of the Netherlands, the then smaller confines of the capitalist world system. Each of the three hegemons had empires, and those empires contributed at key historical moments to building and sustaining hegemony, and subsequently limited the Netherlands and Britain's capacities to pursue strategies to sustain hegemony. In contrast, the formal American empire was small and was largely decolonized at the start of the United States' era of hegemony, so it could not play any role in American decline.

Hegemons are hegemons because they have the capacity to set and maintain "rules of the game," which preserve a global social system that ensures their continued supremacy. Why do hegemons lose hegemony? Wallerstein (2011 [1974]) and Arrighi $(1994,2007)$ argue the growing scale of the world system combines with predictable cyclical crises to change the rules of the game. One problem with this argument is that the operation of the world system does not help in predicting the identity of the next hegemon. Nor does it explain why an existing hegemon can't itself vie for hegemony in a transformed world system, as Britain managed to do, in essence succeeding itself as hegemon at the outset of the Industrial Revolution. Wallenstein and Arrighi's focus on the dynamics of the world system leads them to view polities as coherent entities, whose characteristics make them most eligible for hegemony in one era but unqualified in earlier and later periods.

In fact, hegemons like empires contain multiple, competing elites. The actors in world history are elites and classes, not polities. Elite and class conflict repeatedly 


\begin{tabular}{|c|c|c|c|c|c|}
\hline \multirow[t]{2}{*}{ Empires } & \multicolumn{4}{|c|}{ Characteristics of elite structure } & \multirow{2}{*}{$\begin{array}{r}\text { Achieved } \\
\text { hegemony }\end{array}$} \\
\hline & $\mathrm{C}$ & A & $U$ & I & \\
\hline Spanhish & 1 & 1 & 0 & $0 / 1$ & 0 \\
\hline French & 1 & 1 & 0 & 0 & 0 \\
\hline Dutch & 0 & 0 & 0 & 0 & 1 \\
\hline British & 0 & 0 & 0 & 0 & 1 \\
\hline U.S. & 0 & 0 & 0 & 0 & 1 \\
\hline Napoleonic & 0 & 0 & 1 & 0 & 0 \\
\hline Nazi & 0 & 0 & 1 & 0 & 0 \\
\hline Ancient Roman & 0 & 1 & 0 & 1 & 0 \\
\hline Ottomans & 0 & 1 & 0 & 1 & 0 \\
\hline
\end{tabular}

Figure 4 Boolean truth table of elite structure and hegemony

$\mathrm{C}=$ high level of elite conflict in metropole; $\mathrm{A}=$ high level of colonial elite autonomy from metropole; $\mathrm{U}=$ unitary elite dominant in metropole; I = lack infrastructural capacity to impose economic hegemony

change the structure of each polity and thereby change that polity's capacity to vie for or sustain hegemony. While the world systems approach can recognize and address elite and class conflict, I take issue with Wallerstein and Arrighi's efforts to synchronize structural change within polities to the cycles of the world system. In actuality, the politics of each empire or hegemon was idiosyncratic and can best be understood by tracing contingent chains of conflict and structural change to determine their affects on each hegemon and putative hegemon's capacity to set and enforce global rules of the game. This article provides a framework for engaging in that task by noting that colonial elites are central actors in these polities' dynamics of conflict and structural change, and that the dynamic occurs within different parameters in each of the four quadrants of figure 2.

Only where colonial elites had a low level of autonomy could a polity attain the coherence to set a global strategy and mobilize resources necessary to vie for hegemony. The high degree of elite conflict and institutional incoherence in early modern Spain and France and within their empires doomed the efforts of the Hapsburgs and Louis XIV to parlay their commanding military and geopolitical positions in Europe into hegemony. Napoleon and Hitler were able to impose coherence and discipline in their metropoles and empires, but the fact that their empires in their short lives were pure creations of a unitary metropolitan elite led inevitably to a military rather than economic strategy for creating dominance that brought on the combined responses of the other great powers, ensuring France and Germany's defeats. The similar military foci of the Habsburgs and Louis XIV also can be analyzed as emanations of the limits imposed by high levels of elite autonomy and conflict in the Spanish and French metropoles and early modern empires.

Paul Kennedy (1987), among many other scholars, has argued that hegemony in Europe was impossible, that each effort to attain it brought on led the other 
powers to united to defeat the putative continental hegemon. We need to ask why Spain, France, and in the twentieth century Germany took that route while Netherlands and Britain took their quests for power beyond Europe and constructed global hegemonies, as did the United States in the twentieth century. Those strategies were not dictated by geography or unusually martial national cultures. Continental militarism was the only path open to metropolitan elites who were divided among themselves (or under Napoleon and Hitler melded into one) and unable to subordinate colonial elites or create a sufficient non-European empire before engaging rival powers geopolitically or economically.

The quest for hegemony is made possible in the first instance by conditions internal to each polity, just as internal conditions foreclosed the possibility of hegemony in other polities. That is why Go is correct to argue that we must "compare [empires, and I would add hegemons] across comparable historical phases" (2011: 21).

Go's analysis is different from world systems theorists because he shows how an empire's institutional and cultural forms, which were established before that empire achieved hegemony, determines how an empire is able to take advantage of the opportunities that world hegemony gives to deepen its imperial exploitation, and how empires employ those long-standing structures to manage their loss of hegemony. For Go, imperial policy is shaped by, but not derived from, a polity's geographic and temporal location in the world system. He brings imperialists back into the study of empire and shows how those actors inhabit institutions and possess beliefs and practices that variously limit or enhance their abilities to navigate geopolitical flux.

I hypothesize that colonial elites in the three hegemons, during what Go labels the phases of "hegemonic assent" and "hegemonic maturity," had low levels of conflict because they were bound together in institutions that within the metropole regulated elite relations in ways that reduced conflicts and stabilized the distribution of resources and power. Those institutions structured the way in which metropolitan elites achieved concessions and exercised power in colonies, both formal and informal. Polities with such elite unity were better able to mobilize resources for seizing colonies and then holding them against rival elites. Colonial elites from such polities were more closely integrated with, and subordinated to, metropolitan elites, which facilitated the extraction of resources by the metropole and also allowed the metropole to leverage their colonial and neo-colonial holdings to create hegemony in production, trade and finance.

The stability of relations among elites is what distinguishes the three polities that became hegemons from all other modern polities that amassed empires but did not achieve hegemony. While Napoleonic France and Nazi Germany also had stable elite relations, because one elite achieved total control within the metropole, the identity of that single elite - a military or party elite - combined with the previous absence of a significant empire to dictate a military strategy of conquest that precluded the construction of global hegemony. The ancient Roman and Ottoman Empires also had elite stability, but lacked the infrastructural capacity to penetrate their colonial holdings in a way that could transform them and impose economic as well as a geopolitical hegemony. 

re 4)

We can summarize this discussion with another Boolean truth table (see figu-

Four factors can prevent a polity, even one with an extensive empire, from achieving global hegemony: (1) a high level of elite conflict in metropole, (2) a high level of colonial elite autonomy from metropole, (3) a unitary elite which achieves dominance over all other elites, in essence eliminating them as elites, in the metropole, and (4) the lack of infrastructural capacity to impose economic hegemony in conquered or dominated lands. For the ancient and Ottoman empires the lack of infrastructural capacity allowed colonial elites to achieve a high level of autonomy, foreclosing the possibility of hegemony. For early modern Spain and France, high levels of elite conflict in the metropole allowed a high level of colonial elite autonomy, again blocking the creation of hegemony. Napoleon and Hitler ruled polities that were blocked from hegemony by the single factor of a unitary elite. Only the Netherlands, Britain and the United States did not face a single structural factor that could have prevented the hegemony that all three achieved.

Why did the three hegemons each lose hegemony in the phase Go labels "competition/decline?" If the overall structure of my argument is correct, hegemony itself must have created one or more of the four factors that blocked hegemony for the other empires. I hypothesize that hegemony affected the first factor, that it disrupted stable elite relations and heightened elite conflict in the metropole. The question then becomes: Through what process did hegemony affect metropolitan elite relations?

Hegemony brought great wealth, but it also restructured the political economy of the metropole. Some metropolitan and colonial elites gained resources and leverage over resources and the state at the expense of other elites. (Arrighi for the most part is correct that financial elites were the greatest beneficiaries of hegemony.) This in turn either heightened elite conflict or allowed privileged elites to solidify their authority over sectors of the state and economy. While no elite in a hegemon achieved the unitary power of the ruling elite in Napoleonic France or Nazi Germany, elites in the Netherlands and recently in the United States succeeded in appropriating sectors of the economy and the state for their exclusive benefit. Britain maintained its hegemony longer than the Netherlands or the U.S. because the balance of elite forces was more durable than in the other two hegemons.

The theoretical assertions in this article need to be tested against the historical evidence from Spain, France, and the three hegemons. We need to trace the specific chains of contingent action that led the three polities to achieve and lose hegemony, and the other two powers to fall short. In so doing, we also will be able to explain the particular relations of power that were left after the end of hegemony and so elucidate the choices that were open to elites and non-elites in the Netherlands and Britain as they underwent decline, and the actual choices the United States now faces. 


\section{References}

Aly, Gotz (2005), Hitler's Beneficiaries: Plunder, Racial War, and the Nazi Welfare State, New York, Metropolitan.

Anderson, Perry (1974), Passages from Antiquity to Feudalism, London, New Left Books.

Arrighi, Giovanni (1994), The Long Twentieth Century. Money, Power, and the Origins of Our Times, London, Verso.

Arrighi, Giovanni (2007), Adam Smith in Beijing. Lineages of the Twenty-First Century. London, Verso.

Barkey, Karen, (2008), Empire of Difference. The Ottomans in Comparative Perspective, Cambridge, Cambridge University Press.

Breen, T. H. (2004), The Marketplace of Revolution. How Consumer Politics Shaped American Independence, New York, Oxford University Press.

Elliott, John H. (2006), Empires of the Atlantic World. Britain and Spain in America, 1492-1830, New Haven, Yale University Press.

Go, Julian (2011), Patterns of Empire. The British and American Empires, 1688 to the Present, New York, Cambridge University Press.

Greene, Kevin (1986), The Archaeology of the Roman Empire, London, Batsford.

Hanson, Victor Davis (1989), The Western Way of War. Infantry Battle in Classical Greece, New York, Knopf.

Hopkins, Keith (2009), “The political economy of the Roman empire”, in Ian Morris, and Walter Scheidel (eds.), The Dynamics of Ancient Empires. State Power from Assyria to Byzantium, New York, Oxford University Press, pp. 178-204.

Kennedy, Paul (1987), The Rise and Fall of the Great Powers. Economic Change and Military Conflict from 1500 to 2000, New York, Random House.

Lachmann, Richard (2000), Capitalists in Spite of Themselves. Elite Conflict and Economic Transitions in Early Modern Europe, New York, Oxford University Press.

Mahoney, James (2010), Colonialism and Postcolonial Development. Spanish America in Comparative Perspective, Cambridge, Cambridge University Press.

Mann, Michael (1986, 1993, 2012), The Sources of Social Power, vols. 1, 2 and 3, Cambridge, Cambridge University Press.

Mann, Michael (2004), Fascists, Cambridge, Cambridge University Press.

Mazower, Mark (2008), Hitler's Empire. How the Nazis Ruled Europe, New York, Penguin.

Porter, Bernard (1984), The Lion's Share. A Short History of British Imperialism 1850-1983, London, Longman (second edition).

Riley, Dylan (2004), “Enigmas of fascism”, New Left Review, 30, pp. 134-147.

Ste. Croix, G. E. M. de (1981), The Class Struggle in the Ancient Greek World. From the Archaic Age to the Arab Conquests, Ithaca, Cornell University Press.

Steinmetz, George (2007), The Devil's Handwriting. Precoloniality and the German Colonial State in Qingdao, Samoa, and Southwest Africa, Chicago, University of Chicago Press.

Steinmetz, George (2008), "The colonial state as a social field", American Sociological Review, 73, pp. 589-612.

Wallerstein, Immanuel (2011 [1974]), The Modern World System, vols. 1-4, Berkeley, University of California Press.

Wells, Colin (1984), The Roman Empire, Stanford, Stanford University Press. 
Wieshöfer, Josef (2009), "The Achaemenid empire”, in Ian Morris, and Walter Scheidel (eds.), The Dynamics of Ancient Empires. State Power From Assyria to Byzantium, New York, Oxford University Press, pp. 66-98.

Richard Lachmann. Professor at State University of New York at Albany, College of Arts and Sciences, Sociology Department, 1400 Washington Ave, Arts \& Sciences, 351, Albany, New York 12222. E-mail: rlachmann@albany.edu

Received: 26 de dezembro de 2013. Approved: 19 de fevereiro de 2014 